\title{
Anomalous thermal maturities caused by carbonaceous sediments
}

\author{
Henry N. Pollack ${ }^{*}$ and Karen Rose Cercone† \\ - Department of Geological Sciences, The University of \\ Michigan, Ann Arbor, MI 48109-1063, USA \\ + Geoscience Department, Indiana University of \\ Pennsylvania, Indiana, PA 15705-1087, USA
}

\begin{abstract}
Sedimentary rocks such as coal and carbonaceous mudstone which contain abundant carbonaceous matter are characterized by thermal conductivity much lower than that exhibited by other common rock types, by a factor of 5-10. As a result, temperature gradients in such sediments can range up to $0.25^{\circ} \mathrm{C} \mathrm{m}^{-1}$ even under conditions of average heat flow. When such steep gradients extend over a significant sedimentary thickness, temperatures of underlying rock units are elevated, causing both organic and inorganic phases to record what seem to be anomalously high levels of thermal maturity. This carbonaceous blanket insulating effect may help to explain unusual levels of maturity observed at shallow depths in the Appalachian Basin, Michigan Basin and other regions of the world with significant carbonaceous strata.
\end{abstract}

\section{INTRODUCTION}

A common observation in many sedimentary basins is the occurrence of high thermal maturities, as indicated by coal rank, vitrinite reflectance, conodont alteration indices, fission-track annealing histories, fluid inclusion homogenization behaviour or other geological parameters, at the surface or at shallow depths of burial. Because normal geothermal gradients could not produce the palaeotemperatures suggested by these indicators at their current burial depths, such maturities have been termed anomalous. Many recent studies have explained the presence of anomalous thermal maturities as evidence for former tectonic events involving significantly higher heat flow or large regional uplift and erosion. In this study, we present an alternative hypothesis that offers an explanation for anomalous thermal maturities simply as a consequence of a relatively thin thermal blanket comprising low-thermal-conductivity carbonaceous sediments, a common class of sedimentary rock.

\section{PREVIOUS INTERPRETATIONS}

Anomalously high thermal maturity measurements in sedimentary basins have been cited by some investigators as evidence for large-scale regional events. In some cases, erosion of several kilometres of overburden has been inferred to bring formerly dceply buried sediments closer to the surface. For example, Friedman (1987), Miller \& Duddy (1989) and Zhang \& Davis
(1993) have postulated that the high thermal maturities of Palaeozic rocks in the northern Appalachian Basin resulted from the erosion of several kilometres of sediment during the Alleghenian orogeny. Similarly, Crowley et al. (1986), Crowley (1991) and Arne (1992) have interpreted fission-track annealing histories as evidence for several kilometres of erosion in the northern mid-continent and Ouachita-Arkoma Basin regions of the United States, respectively. Other workers have invoked higher than normal heat flows (and thus higher than normal geothermal gradients) as an explanation for unusual maturities. Examples of the latter approach include studies of the Rhine basins by Teichmuller \& Teichmuller (1986), of the Appalachian Basin by Hower \& Davis (1981) and of the Michigan Basin by Cercone (1984).

In many cases, however, neither an erosional nor an above-normal heat flow hypothesis can provide a satisfactory explanation of anomalous thermal maturities. Great amounts of erosion require a tectonic mechanism for uplift which is not always available. Moreover, in some areas adjacent uneroded regions provide stratigraphic constraints that do not permit the reconstruction of great thicknesses of former overburden over the area of interest. Similarly, high heat flow from the basement requires a causative thermal event in the lower crust or upper mantle which typically would be accompanied by magnetic and diagenetic overprints and later followed by subsidence, evidence for which is absent in many anomalously mature settings. In addition, the presence of high geothermal gradients throughout a sedimentary 
sequence could cause the sediments lowest in the section to show extremely high thermal maturities or to become metamorphically altered, effects which are seldom observed. Nunn (1986) recognized such difficulties in most extant models of the thermal history of the Michigan Basin sediments, and suggested that perhaps the hydrocarbons resident in that basin had acquircd higher levels of maturity at greater depths, later to migrate to their present shallow depths. In this paper we offer another possible explanation of anomalous thermal maturities, without recourse to extraordinary thermal or tectonic events, an explanation that has its origin in the sedimentary sequence itself.

\section{THE CARBONACEOUS SEDIMENT BLANKET HYPOTHESIS}

Many sedimentary basins contain sections of coals, carbonaceous mudstones or other organic-rich rocks. These carbonaceous units are characterized by thermal conductivity in the range $0.25-1.0 \mathrm{~W} \mathrm{~m}^{-1} \mathrm{~K}^{-1}$, significantly lower than the conductivity of most other sedimentary lithologies by a factor of 5-10 (Blackwell \& Steele, 1989). We call attention to the fact that the low thermal conductivity of these units will be accompanied by steep temperature gradients through the carbonaceous section, even under the conditions of average or below average heat flow common to many basin and platform settings. The high temperature gradient across even modest thicknesses of carbonaceous section leads to a significant increment in temperature. As the temperature at the base of the carbonaceous section is also the temperature at the top of the underlying strata, the temperature throughout the underlying units is higher by an amount equal to the increase of temperature across the carbonaceous section, even though the heat flow is uniform and the gcothermal gradient below the carbonaceous section is ordinary. This temperature increment to the underlying units causes them to become significantly more thermally mature than would be caused by burial to the same depth bencath ordinary scdiments. The large but uniform increment of temperature below the carbonaceous blanket contrasts with a variable temperature increment proportional to the depth of burial which would arise from an increased basement heat flow. The carbonaceous blanket thus avoids the decp 'over-maturity' consequence of an increascd heat flow hypothesis.

Evidence demonstrating the thermal blanket effect was recently obtained by one of us (H.N.P.) as part of a regional heat flow measurement programme in southern Africa (Ballard et al., 1987). Tcmperature measurements in the Karoo coal measures of eastern Botswana yielded thermal gradients well in excess of $0.1^{\circ} \mathrm{C} \mathrm{m}^{-1}$, whereas in the crystalline basement beneath or nearby the coal basins the temperature gradient was typically less than $0.02^{\circ} \mathrm{C} \mathrm{m}^{-1}$ (Fig. 1). The thickness of the coal measures in this area is about $100-150 \mathrm{~m}$, and the temperature increases across the carbonaceous section are in the range $8-10^{\circ} \mathrm{C}$. The regional heat flow in this area is about $45 \mathrm{~mW} \mathrm{~m}^{-2}$, a value characteristic of many Archaean cratons but well below the worldwide average of $65 \mathrm{~mW} \mathrm{~m}^{-2}$ for continents and the global average of $87 \mathrm{~mW} \mathrm{~m}^{-2}$ (Pollack et al., 1993).

The thermal conductivity of the lithologies present in the Karoo section (Fig. 2) ranges over a full order of magnitude, from less than $0.5 \mathrm{~W} \mathrm{~m}^{-1} \mathrm{~K}^{-1}$ for coal and $1.0 \mathrm{~W} \mathrm{~m}^{-1} \mathrm{~K}^{-1}$ for carbonaceous mudstones to grcater than $3.0 \mathrm{~W} \mathrm{~m}^{-1} \mathrm{~K}^{-1}$ for quartz. sandstones. The average

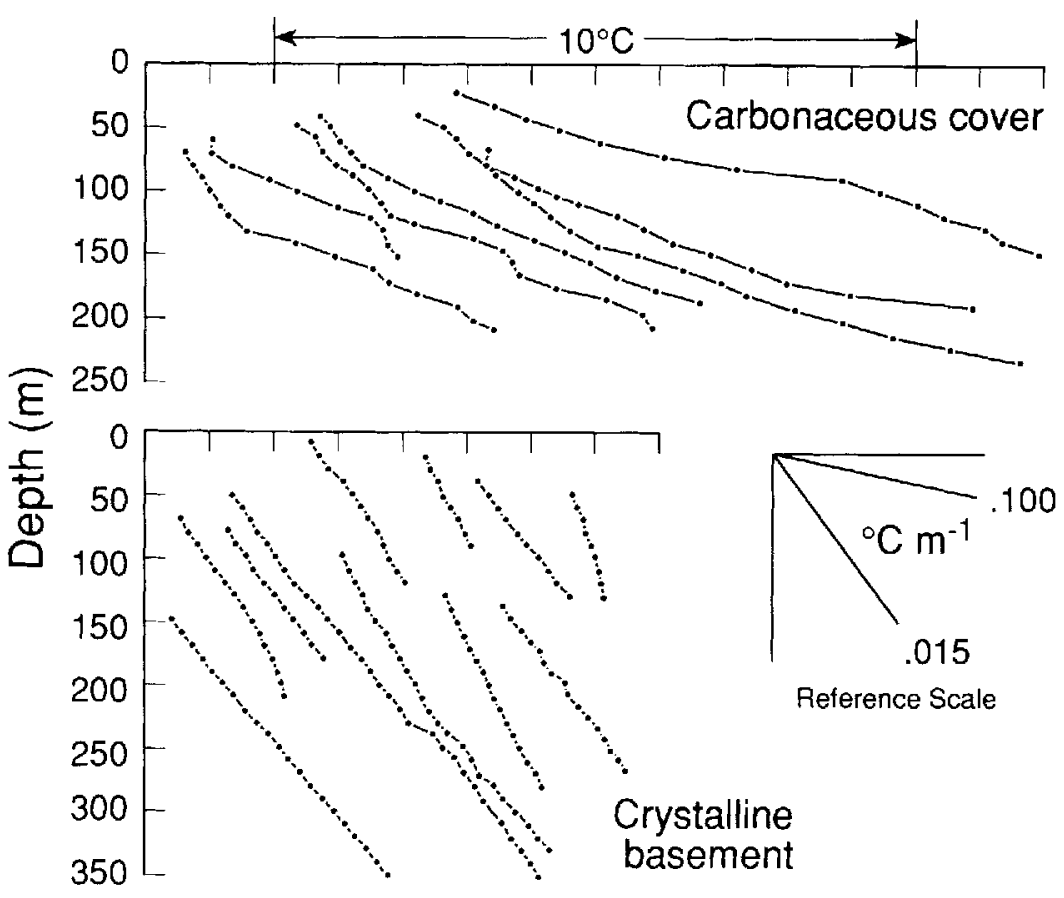

Fig. 1. Temperatures vs. depth logs of several boreholes in and nearby Karoo coal basins in Botswana. The upper group of boreholes are in carbonaceous sediments, and the lower group are in adjacent crystalline basement; the profiles are offset arbitrarily to avoid overlap. Crustal heat flow is uniform throughout the area. The slope of lines in the reference scale provides a visual comparison of temperature gradients. 

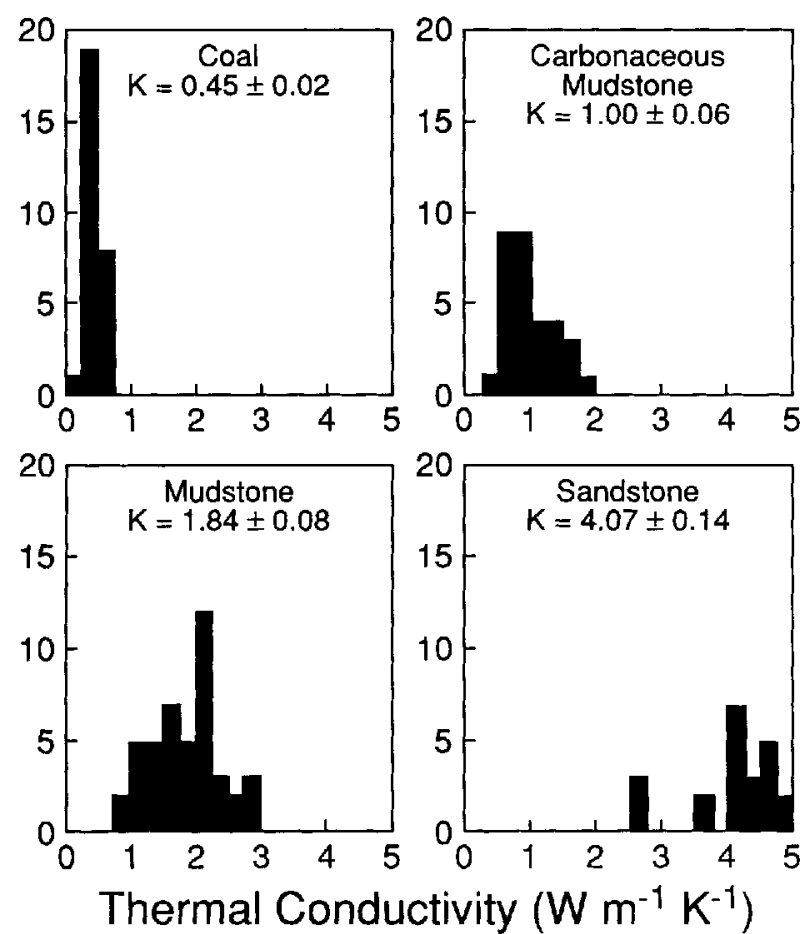

Fig. 2. Histograms of thermal conductivity measurements of coal, carbonaceous mudstone, mudstone and sandstone from the Karoo coal basins in eastern Botswana (from Ballard et al, 1987; copyright the American Geophysical Union).

conductivity of the crystalline basement in the area is about $3.3 \mathrm{~W} \mathrm{~m}^{-1} \mathrm{~K}^{-1}$. Stated another way, for a given heat flow the temperature increment across $1 \mathrm{~m}$ of coal is about the same as across $10 \mathrm{~m}$ of sandstone or $6.5 \mathrm{~m}$ of the crystalline basement; thus, the significance of relatively small thicknesses of carbonaceous deposits is apparent.

Coal-bearing units in other areas have been found to have similarly low conductivities and high thermal gradients. A study of Jurassic coal deposits in Australia by Beck (1976) revealed gradients as high as $0.14^{\circ} \mathrm{C} \mathrm{m}^{-1}$, while Kayal \& Christoffel (1982) found gradients through Gondwana coals in India to range from 0.04 to $0.25^{\circ} \mathrm{C} \mathrm{m}^{-1}$, leading to a $6^{\circ} \mathrm{C}$ increment over a $50-\mathrm{m}$ interval. Blackwell \& Steele (1988) also report low thermal conductivities and associated high gradients for coal and carbonaceous rocks, calling special attention to a 'spectacular' $15^{\circ} \mathrm{C}$ temperature increment over a $250-\mathrm{m}$ coal-bearing depth interval in a borehole in north-western Colorado.

The presence of such large temperature steps across carbonaceous sections has generally gone unnoticed in most petroleum boreholes because they are not usually subjected to a continuous temperature vs. depth log, which would reveal a steep gradient interval if present. The more common temperature measurement is simply a bottom-hole temperature taken after the completion of drilling. The anomalous temperature increase across a few hundred metres of carbonaceous section, when averaged over a few thousand metres of total depth, does not attract attention.

The effect of low-conductivity carbonaceous sediments on the thermal condition of a sedimentary basin is summarized in Fig. 3. Because the carbonaceous thermal blanket warms only the strata beneath it, its effect on the thermal regime of a basin will be greatest when the carbonaceous rocks lie close to or at the top of the sedimentary sequence. The elevated temperatures will persist for as long as the carbonaceous unit resides overhead, provided that it does not become either so compacted or so permeable that the effective thermal conductivity increases and the insulating effect is impaired. The magnitude of the carbonaceous blanket temperature increment will vary from region to region, (a)

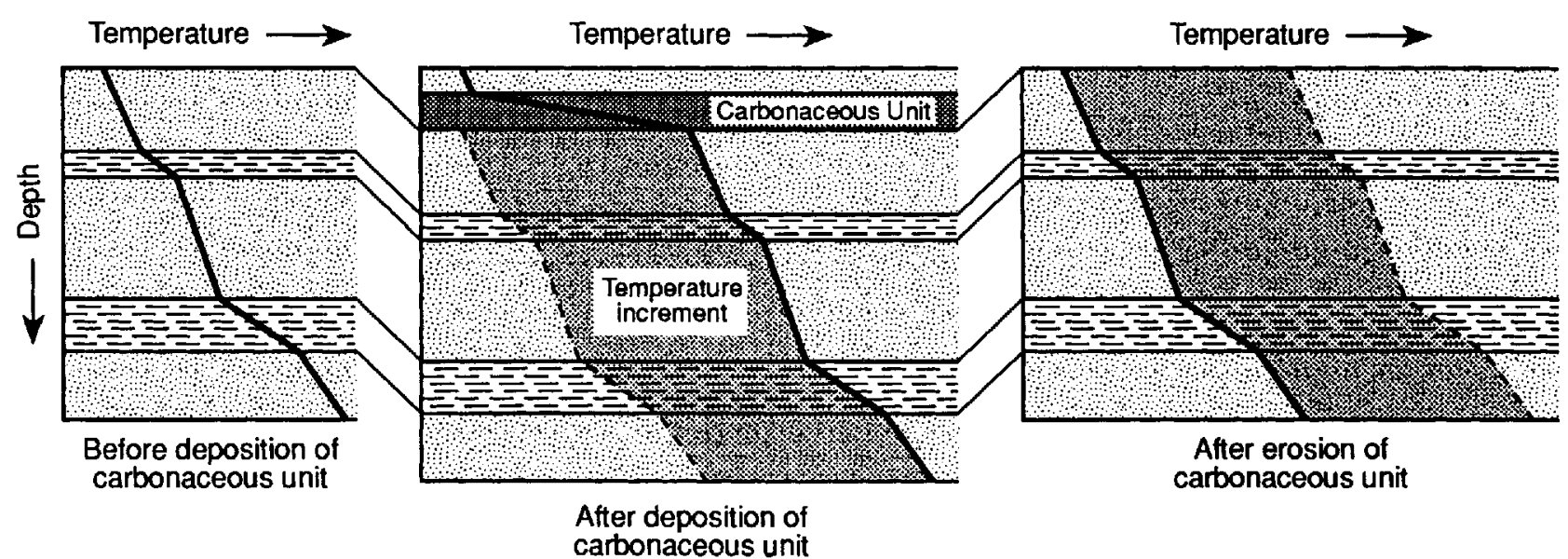

Fig. 3. Schematic temperature versus depth plot through a sedimentary section showing the carbonaceous blanket effect on subsurface temperatures. Temperatures in the absence of a blanket are shown in (a), temperatures with a blankct in (b), and temperatures after removal of blanket in (c). Dashed temperature profiles in (b) and (c), respectively, show the temperature profile from the previous panels (a) and (b) for reference. The temperature increment due to the carbonaceous unit is shaded. 
since it is determined by the regional heat flow, and the thickness and average organic content of the carbonaceous section. Figure 1 shows temperature increments of $10^{\circ} \mathrm{C}$ over a $150-\mathrm{m}$ depth interval, and as mentioned earlier Blackwell \& Steele (1988) describe a $15^{\circ} \mathrm{C}$ increment over a $250-\mathrm{m}$ depth interval in the coal-bearing paludal sequence at the base of the Mesa Verde Formation of the Piccance Basin in western Colorado.

Temperature is the strongest factor in all models of organic maturation. The simplest model of the influence of tempcraturc ascribes a factor of two increase in reaction rates for every $10^{\circ} \mathrm{C}$ increase in temperature (Lopatin, 1971; Waples, 1980). More elaborate models include parallel Arrhenius reactions with a distribution of activation energies (Quigley \& Mackenzie, 1988; Sweency \& Burnham, 1990; Hunt et al., 1991) in which individual reaction rates are exponential functions of temperature. In either type of kinetic model the long-term increase in temperature caused by a blanket of carbonaceous sediments should be extremely significant in the formation of liquid and gaseous hydrocarbons or maturation of coal deposits within a sedimentary basin. Bostick \& Freeman (1984) call attention to anomalously high vitrinite reflectance in the decper sections of the well in which Blackwell and Steele observed the carbonaceous blanket effect. Other studies (Kamp \& Green, 1990; Waples et al., 1992) also record variations in thermal maturity which appear to correlate with the distribution of overlying carbonaceous sediments. Cercone \& Pollack (1991) have invoked the carbonaceous thermal blanket effect as a possible explanation of the anomalously high thermal maturities at shallow depths in the Michigan Basin. We conclude that a failure to take into account in thermal models the insulating effect of carbonaceous sediments could lead to serious underestimates of thermal maturity in underlying strata. This could influence not only the predicted window of hydrocarbon generation within a basin, but also its potential as a source of mineralizing thermal fluids for ore deposits.

The suggestion that carbonaceous sediments can lead to anomalously high thermal maturities in the scdimentary section beneath does not mean that the alternative hypotheses of erosion and high heat flow must always be rejected. There are many areas where no case can be made for the presence, now or in the past, of a carbonaceous section, and where erosion or high heat flow can be documented not only by anomalously high thermal maturity indices but by other geological evidence as well. We argue only that thermal models of any stratigraphic section which contains highly organic-rich marine shales or coal-bearing fluvial/deltaic deposits should take into account the effects of the very low thermal conductivity of these rock types. In some cases, these effects may be sufficient to explain higher thermal maturity values in underlying rocks without calling upon obscure tectonothermal events to provide deep erosion and/or high heat flow.

\section{CONCLUSIONS}

Sedimentary rocks which contain abundant carbonaceous material have much lower thermal conductivities than many other rock types. The presence of such units in a stratigraphic section results in anomalously high temperature gradients through the carbonaceous interval, and a significant increase of temperature across it. Underlying rocks arc thus warmer by the amount of the anomalous increase in temperature across the carbonaceous section, even under conditions of average heat flow. As a result, thermal maturities of the underlying units may become anomalously high. Because this insulating blanket warms only the strata beneath it, the volume of rock affected by it is greater when the blanket occurs at shallow depths in the basin. We suggest that thermal models of sedimentary sequences with carbonaceous rocks should take this insulating effect into account, in order to arrive at an accurate estimate of the thermal, burial and tectonic history of the region.

\section{REFERENCES}

ArNi, 1). C. (1992) Exidence from apatite fission-track analysis for rcgional Crctaceous cooling in the Ouachita Mountain fold belt and Arkoma Basin of Arkansas. Bull. Am. Ass. petrol. Geol., 76, 394-402.

Ballakd, S., Potlack, H. N. \& SkINNHK, N. J. (1987) Terrestrial heat flow in Botswana and Namibia. 7. geophys. Res., 92, 6291-6300.

Bl:ck, A. E. (1976) The use of thermal resistivity logs in stratigraphic correlation. Geophysics, 41, 300-309.

Bl.arkwfis, D. \& STtilis, J. (1988) Thermal conductivity of sedimentary rocks--measurement and significance. In: Thermal History of Sedimentary Basins (F.d. by N. Naeser and T. McCulloh). Springer, New York.

Bostick, N. II. \& Fritiman, V. L. (1984) Vitrinite reflectance and paleotemperature models testcd at DOE's multiwell experiment in the Piceance Basin, Colorado. US geol. Surz: Repurt EMG-OGR.

CrecoN, K. R. (1984) Thermal history of Michigan basin. Bull. Am. Ass. petrol. Geol., 68, 130-136.

Cikcomis, K. R. \& Poll.ack, H. N. (1991) Thermal maturity of the Michigan Basin. In: Early Sedimentary Evolution of the Michigan Basin (Ed. by P. A. Catacosinos and P. A. Daniels Jr), Spec. Paper geol. Soc. Am., 256, 1-11.

Crowley, K. D. (1991) Thermal history of the Michigan Basin and southern Canadian Shield from apatite fission track analysis. f. geophys. Res., 96, 697-711.

Clrowt.ly, K. D., Nalsist, C. W. \& Babili, C. A. (1986) Tectonic significance of Precambrian apatite fission-track ages from the midcontinent United States. Earth planet. Sci Lett., 79, 329-336.

Frifdman, G. M. (1987) Vertical movements of the crust: case histories from the northern Appalachian basin. Goology, $15,1130-1133$.

Howre, J. C. \& Davis, A. (1981) Application of vitrinite reflectance anisotropy in the evaluation of coal metamorphism. Bull. geol. Soc. Am., 92, 350-366.

Hunt, J. M., Llwan, M. D. \& Hiani:1, R. J.-C. (1991) Modeling oil generation with time-temperature index graphs 
based on the Arrhenius equation. Bull. Am. Ass. petrol. Geol., 75, 795-807.

Kamp, P. J. J. \& Gref.n, P. F. (1990) Thermal and tectonic history of selected Taranaki Basin (New Zealand) wells assessed by apatitc fission track analysis. Bull. Am. Ass. petrol. Geol., 74, 1401-1419.

Kayal, J. R. \& Christoffel, D. A. (1982) Relationship between electrical and thermal resistivities for differing grades of coal, Geophysics, 47, 121-129.

Lopatin, N. V. (1971) Temperature and geologic time as factors in coalification. Izv. Akad. Nauk USSR. ser Geol., 3, 95-106.

Miller, D. S. \& Duddy, I. R. (1989) Early Cretaceous uplift and erosion of the northern Appalachian Basin, New York, based on apatite fission track analysis. Earth planet. Sci. Lett., 93, 35-49.

Nunn, J. A. (1986) Subsidence and thermal history of the Michigan Basin. In: Thermal Modeling in Sedimentary Basins (Ed. by J. Burrus), pp. 417-436. Editions Technip, Paris.

Pollack, H. N., Hurter, S. J. \& Johnson, J. R. (1993) Heat flow from the Larth's interior: analysis of the global data set. Rev. Geophysics, 31, 267-280.

Quigley, T. M. \& MacKenzie, A. S. (1988) The temperatures of oil and gas formation in the sub-surface. Nature, 333, 549-552.

Sweeney, J. J. \& Burnham, A. K. (1990) Evaluation of a simple model of vitrinite reflectance based on chemical kinetics. Bull. Am. Ass. petrol. Geol., 74, 1559-1570.

Teichmuilfir, R. \& Teichmut.t.r, M. (1986) Relations between coalification and paleogeothermics in Variscan and Alpidic foredeeps of western Europe: In: Paleogeothermics (Ed. by G. Buntebarth and L. Stegena), pp. 53-78. Springer-Verlag, New York.

WAPLES, D. W. (1980) Time and temperature in petroleum formation: application of Lopatin's method to petroleum exploration: Bull. Am. Ass. petrol. Geol., 64, 916-926.

Waples, D. W., Kamata, H. \& Suizi, M. (1992) The art of maturity modeling. Part 1 . Finding a satisfactory geologic model. Bull. Am. Ass. petrol. Geol., 76, 31-46.

Zhang, E. \& Davies, A. (1993) Coalification patterns of the Pennsylvanian coal measures in the Appalachian foreland basin, western and south-central Pennsylvanai. Bull. geol. Soc. Am., 105, 162-174.

Received 11 August 1993; revision accepted 10 March 1994. 